\title{
Yaşam Boyu Gelişimde Motivasyon Kuramı Çerçevesinde Kontrol Stratejilerinin İncelenmesi
}

\section{The Investigation of Control Strategies within the frame of Motivational Theory of Life-Span Development}

\author{
Deniz $\operatorname{Kurt}^{1}$ (), Zehra Uçanok ${ }^{2}$ (1)
}

Yazar Notu: Bu çalışma ilk yazarın doktora tezinin bir parçasıdır.

'Dr. Öğr. Üyesi, Uşak Üniversitesi, Fen Edebiyat Fakültesi, Psikoloji Bölümü, Uşak, Türkiye

${ }^{2}$ Prof. Dr., Hacettepe Üniversitesi, Edebiyat Fakültesi, Psikoloji Bölümü, Ankara, Türkiye

ORCID: D.K. 0000-0002-0904-2886 Z.U. 0000-0003-3953-300X

Sorumlu yazar/Corresponding author: Deniz Kurt,

Uşak Üniversitesi, Fen Edebiyat Fakültesi, Psikoloji Bölümü, Uşak, Türkiye

E-posta/E-mail: denizkurt7@gmail.com

Başvuru/Submitted: 24.05.2019

Kabul/Accepted: 26.11.2019

Online Yayın/Published Online: 10.04.2020

Atıf/Citation: Kurt, D., Ucanok, Z. (2020). Yaşam boyu gelişimde motivasyon kuramı çerçevesinde kontrol stratejilerinin incelenmesi. Psikoloji Çalışmaları - Studies in Psychology. Advance online publication. https://doi.org/10.26650/SP2019-0040

\section{ÖZ}

Araştırmanın temel amacı Yaşam Boyu Gelişimde Motivasyon Kuramı (Heckhausen, Wrosch ve Schulz, 2010) çerçevesinde, genç bireylerin belirledikleri bir hedefe ulaşma sürecinde başvurdukları kontrol stratejilerinin neler olduğunu incelemektir. Araştırmanın örneklemini yaşları 18 ile 30 arasında değişen 396 katılımcı oluşturmaktadır. Katılımcıların 214'ü kadın (\%54), 182'si (\%46) erkektir. Yaş ortalaması ise 23.92'dir ( SS = 3.80). Katılımcılar en az lise mezunudur. Katılımcılardan ilk olarak lise veya üniversite yıllarında belirlemiş oldukları hedefi hatırlamaları ve bu hedefe ulaşma sürecinde bir engel ya da başarısızlıkla karşılaşmaları durumunda başvurdukları kontrol stratejilerinin neler olduğunu belirtmeleri istenmiştir. Katılımcılara ayrıca Optimizasyon ve Kontrol Stratejileri Ölçeği uygulanmıştır. Çalışma kapsamında belirlenen hedefle ilgili olarak yakın çevredeki bireylerden ne ölçüde destek algılandığı da incelenmiştir. Yaşam Boyu Gelişimde Motivasyon Kuramı (Heckhausen ve ark., 2010) çerçevesinde yürütülen niteliksel veri analizi sonucunda verilen yanıtların önemli bir çoğunluğu seçici birincil kontrol ve ödünleyici birincil kontrol stratejileri kapsamında sınıflandırılmıştır. Bu iki stratejiyi seçici ikincil kontrol stratejisi izlemiştir. Katılımcılar tarafından en az başvurulan kontrol stratejisinin ise ödünleyici ikincil kontrol stratejisi olduğu görülmüştür. Tek Faktörde Tekrar Ölçümlü ANOVA sonuçları da ödünleyici ikincil kontrol stratejisinin diğer kontrol stratejilerine kıyasla katılımcılar tarafından daha az kullanıldığına işaret etmektedir. Ayrıca bireylerin hedefe ulaşma sürecinde en çok annelerinden destek algıladıkları görülmüştür. Çalışma kapsamında zamana ve çabaya yatırım yapma, tekrardan deneme, mücadele etme, yeni yöntemlere başvurma, diğer insanlardan yardım ve tavsiye isteme gibi stratejilerin katılımcılar tarafindan daha çok kullanıldığı ortaya konulmuştur. Elde edilen bu yöndeki sonuçlar, genç bireylerin belirledikleri hedeflere ulaşma sürecinde bir engel ya da başarısızlıkla karşılaşmaları durumunda büyük ölçüde çaba harcamaya devam ettiklerine işaret etmektedir.

Anahtar Kelimeler: Gelişimsel hedefler, Yaşam Boyu Gelişimde Motivasyon Kuramı, kontrol stratejileri, lise veya üniversite yılları 


\section{ABSTRACT}

The main purpose of this study is to investigate the control strategies used by individuals in the process of reaching a goal within the frame of the motivational theory of life-span development (Heckhausen, Wrosch, \& Schulz, 2010). The sample consisted of 396 participants aged between 18 and 30 years. 214 (54\%) of the participants were women and 182 $(46 \%)$ of them were men. The mean age of the participants was 23.92 years $(S D=3.80)$. All of the participants were at least high school graduates. The participants were asked to remember the goal they had set for themselves during high school and university years, and to indicate what control strategies they applied if they had encountered an obstacle or a failure in the process of reaching this goal. The Optimization in Primary and Secondary Control Scale was also administered to the participants. In this study, we also examined the perceived support from significant others related to the goal. Qualitative data analysis conducted in the frame of motivational theory of life-span development (Heckhausen et al., 2010) indicated that a significant majority of respondents' answers could be classified as selective primary control and compensatory primary control strategies. These two strategies were followed by selective secondary control. The control strategy which was least used by the participants, was the compensatory secondary control. The results of the One-Way Repeated Measures of ANOVA also revealed that the compensatory secondary control was less frequently used compared to other control strategies. Our findings also showed that participants perceived support mostly from their mothers. The study indicated that participants used strategies such as investing time and effort, trying again and struggling, using new methods, and seeking help or advice from other people more than other strategies. The results also revealed that young individuals who encounter obstacles or failures in the process of reaching their goals mostly continue to strive to achieve their goals.

Keywords: Developmental goals, motivational theory of life-span development, control strategies, high school or university years

\section{EXTENDED ABSTRACT}

High school and university years are a crucial period in which individuals make important decisions about their educational and occupational lives (Nurmi, 2004). Supporting this view, studies point out that individuals focus mostly on goals related to education and occupation during these years (Tynkkynen, Dietrich, \& Salmela-Aro, 2014; Vasalampi, Salmela-Aro, \& Nurmi, 2009). How individuals determine their goals and which strategies are used when encountering an obstacle or a failure in the process of reaching these goals are examined within the scope of many models. One of these models is the motivational theory of life-span development (Heckhausen, Wrosch, \& Schulz, 2010). According to this model, a successful development is possible only when individuals sustain the highest level of control throughout their life course. An important process in the model is optimization. Optimization involves taking into consideration developmental opportunities and time constraints in an attempt to maintain primary control capacities, and it determines the choice of a goal. Besides optimization, four major control strategies have been proposed: selective primary control, which means making an investment of time, effort, and ability; selective secondary control, which means enhancing the goal value and anticipating positive consequences of goal attainment; compensatory primary control, which involves seeking help from others or trying unusual ways to accomplish 
a goal; compensatory secondary control, which includes devaluing the chosen goal and downgrading the importance of the unchosen goal (Heckhausen, 1999; Heckhausen et al., 2010).

The main purpose of this study is to investigate the control strategies used by individuals in the process of reaching a goal within the frame of the motivational theory of life-span development (Heckhausen et al., 2010). Perceived support from significant others related to the goal was also examined.

\section{Method}

The study sample consisted of 396 participants (54\% female). The mean age of the participants was 23.92 years $(S D=3.80)$, and their ages ranged from 18 to 30 years. The Optimization in Primary and Secondary Control Scale was administered to the participants, and an open-ended question was asked to determine the control strategies used. Finally, the participants were asked to rate their perceived goal support on a scale from 1 ("Not at all") to 7 ("Extremely") for each individual (mother, father, peer, romantic partner, and sibling). Research ethics approval was obtained from the Ethics Commission of the University. Participation in the research was voluntary.

\section{Results}

Qualitative data analysis indicated that participants' responses could be classified into seven different categories: selective primary control, selective secondary control, compensatory primary control, compensatory secondary control, nonfunctional strategies, do nothing and others. The results revealed that a significant majority of respondents' answers could be classified as selective primary control and compensatory primary control strategies. "Invest time and effort" and "try again/struggle" are subcategories of the selective primary control, while "use new methods/develop unusual solution", "recruit others' help/get others' advice", and "support from significant others and sharing" are subcategories of the compensatory primary control. The third strategy classified was selective secondary control. "Predict the positive results of achieving a goal/enhance goal value" is a subcategory of the selective secondary control. The control strategy which was the least used by participants is the compensatory secondary control, which includes subcategories "change the goal", "goal disengagement", "self-protective social comparisons" and "goal disengagement at the right time". The results of the quantitative analysis also indicated that the compensatory secondary control was used less by the participants compared to other control strategies. Our findings also showed that participants perceived support mostly from their mothers. 


\section{Discussion}

The study revealed that participants used primary control strategies more than secondary control strategies in the process of reaching a goal determined during their high school and university years. This result can be interpreted as being that young individuals prefer primary control strategies more than secondary control strategies. This finding is consistent with both the basic assumptions of the motivational theory of life-span development (Heckhausen et al., 2010) and the studies in the literature (Uçanok, 2002b; Wrosch, Heckhausen, \& Lachman, 2000). The least used strategy by the participants was compensatory secondary control, which implies that individuals who encounter obstacles in the process of reaching a goal continue to make efforts to achieve the goal and do not give up immediately.

One of the most important limitations of this study was its cross-sectional design. Future longitudinal studies can developmentally examine the changes in control strategies used by individuals over time. On the other hand, the results presented here could not only contribute information to improve many intervention programs, but also school guidance which can be organized to help young people to manage their educational and occupational lives successfully.

In conclusion, the results emphasized that young individuals who encounter obstacles in the process of reaching their goals mostly continue to strive to achieve their goals. Furthermore, investing time and effort to reach his/her goal, trying again and struggling, seeking help or advice from other people seem to be more functional strategies. 
Lise ve üniversite yıllarına karşılık gelen yaşam dönemi bireylerin eğitim yaşantıları ve mesleki tercihleriyle ilgili oldukça önemli kararlar aldıkları bir dönemdir (örn., Nurmi, 2004). Bu görüşü destekler şekilde, çalışmalar lise ve üniversite döneminde bireylerin sıklıkla eğitim ve meslek yaşamlarıyla ilgili hedefler belirlediklerine işaret etmektedir (Chang, Chen, Greenberger, Dooley ve Heckhausen, 2006; Salmela-Aro, Aunola ve Nurmi, 2007; Tynkkynen, Dietrich ve Salmela-Aro, 2014; Vasalampi, Salmela-Aro ve Nurmi, 2009). Ayrıca, eğitim yaşamıyla ilgili hedeflerin zaman içerisinde azaldığı, meslek ve iş yaşamıyla ile ilgili hedeflerin ise arttığ 1 görülmektedir (Kurt ve Uçanok, 2019; Salmela-Aro ve ark., 2007; Tynkkynen ve ark., 2014). Dokuzuncu sınıf öğrencilerinin kariyer hedeflerinin incelendiği boylamsal bir çalışmada, öğrencilerin ağırlıklı olarak eğitim yaşamıyla ilgili hedeflere sahip oldukları ortaya konulmuştur. Yedi yıl sonra yapılan incelemede ise bireylerin artan yaşla birlikte meslek yaşamıyla ilgili hedeflere yöneldikleri görülmüştür (Tynkkynen ve ark., 2014). Lise ve üniversite öğrencilerinin geleceğe ilişkin beklentilerinin incelendiği bir çalışmada ise öğrencilerin gelecek beklentilerinin mesleki başarı, evlilik, ekonomik kazanç ve toplumsal saygınlık alanlarında yoğunlaştığı ortaya konulmuştur (Yavuzer, Demir, Meşeci ve Sertelin, 2005).

İçinde bulunan yaşam dönemiyle bağlantılı olarak eğitim yaşamıyla ilgili bazı geçişler (örn., liseden üniversiteye veya liseden iş yaşamına geçiş) bireyleri kariyerlerine ilişkin daha fazla düşünmeye ve karar almaya zorlamaktadır (Dietrich, Parker ve Salmela-Aro, 2013). Ayrıca günümüzde, lisans ve lisansüstü düzeyde eğitim almak genç bireyler için oldukça yaygın bir amaç halini almıştır. Örneğin, bir incelemede Amerikalı lise öğrencilerinin \%90'ından fazlasının lise eğitimi sonrasında üniversiteye devam etmeyi planladıklar1 ortaya konulmuştur (Schneider ve Stevenson, 1999). Ülkemizde üniversite öğrencileriyle yürütülen bir çalışmada ise öğrencilerin \%60'ının eğitimlerine lisansüstü düzeyde devam etmeyi planladıkları görülmüştür (Şahin, Zoraloğlu ve Fırat, 2011). Nitekim 2019 yılı itibariyle ülkemizde iki milyondan fazla öğrencinin üniversiteye yerleşmek için başvuru yaptığı bilinmektedir. Yükseköğretim Bilgi Yönetim Sistemi istatistiklerine göre üniversiteye başvuran adayların yaklaşık üçte birinin üniversitelere yerleştiği görülmektedir (YÖK, 2019). Üniversiteye başvuran ve yerleşen aday oranının yıllar içerisinde arttığı bilinmektedir. Buna göre, 1980 yılında \%9 olan bu oran, 2019 yılında \%36’ya yükselmiştir. Bununla birlikte birçok genç akademik yaşamlarıyla ilgili yeterli planlama yapamamaları veya ekonomik kaynakların yetersizliği gibi sebeplerden başarısızlıkla karşılaşabilmektedir (Uno, Mortimer, Kim ve Vuolo, 2010). Dolayısıyla bu süreçte genç bireylerin içinde 
bulundukları yaşam koşullarının onlara sunduğu olanakları ve sınırlamaları göz önünde bulundurarak ilgi ve yetenekleri doğrultusunda doğru tercihler yapabilmeleri ve belirledikleri hedefe ulaşma sürecinde karşılaştıkları zorluklarla mücadele edebilmeleri gibi konularda yönlendirme ve desteğe gereksinim duyabilecekleri düşünülmektedir.

Ülkemizdeki mevcut eğitim sistemine göre genç bireylerin geleceğe ilişkin kariyer tercihlerini belirleyecek olan alan seçimi lisenin ilk yıllarında yapılmaktadır. Bireyler bu seçim doğrultusunda bir anlamda tüm yaşamları boyunca yapacakları mesleğe yönelmiş olacaklardır. Dolayısıyla bireylerin geleceğe yönelik belirledikleri hedeflere ulaşma sürecinde bir engel ya da başarısızlıkla karşılaşmaları durumunda, hangi yolları denediklerinin veya hangi yöntemlere başvurduklarının incelenmesi kritik bir öneme sahiptir. Buradan hareketle çalışmanın temel amacı hedefe ulaşma sürecinde herhangi bir engel veya başarısızlıkla karşılaşılması durumunda bireylerin tercih ettikleri stratejilerin incelenmesidir. Belirlenen hedefle ilişkili olarak yakın çevredeki bireylerden (örn., anne, baba, arkadaş vb.) algılanan destek düzeyleri de çalışma kapsamında ele alınmıştır. İlgili alan yazında bireylerin kendi gelişimlerini yönlendirme ve etkileme çabaları ile başarısızlığı ödünlemeye yönelik girişimleri olarak kavramsallaştırılan kontrol stratejilerinin ağırlıklı olarak orta yaş ve yaşlılık dönemlerinde incelendiği dikkati çekmektedir (örn., Dunne, Wrosch ve Miller, 2011; Jobin ve Wrosch, 2016; Schulz ve Heckhausen, 1996). Bu noktadan hareketle, eğitim ve meslek yaşamının büyük ölçüde şekillendiği gelişim döneminde genç bireyler tarafından tercih edilen kontrol stratejilerinin neler olduğu bu araştırmanın temel odak noktası olmuştur. Alan yazındaki diğer çalışmalardan farklı olarak bireylerin ne tür kontrol stratejilerine başvurdukları kendileri için belirledikleri spesifik bir hedef üzerinden incelenmiştir. Elde edilen bulgular ülkemizde genç bireylerin eğitim yaşantıları ve mesleki tercihleriyle ilgili oluşturulacak rehberlik hizmetlerine önemli ölçüde katkı sağlama potansiyeline sahiptir. Bireylerin belirledikleri hedefe ulaşma sürecinde var olan zorluklarla mücadele etmek için hangi yöntemlere başvurdukları, başka bir ifadeyle hangi stratejileri kullandıkları alan yazında birçok model kapsamında incelenmiştir (örn., Baltes ve Baltes, 1990; Freund ve Baltes, 2002; Heckhausen, 1999; Heckhausen, Wrosch ve Schulz, 2010). $\mathrm{Bu}$ çalışmanın odak noktası olan kontrol stratejileri, modellerden biri olan Yaşam Boyu Gelişimde Motivasyon Kuramı (Heckhausen ve ark., 2010) çerçevesinde ele alınacaktır.

\section{Yaşam Boyu Gelişimde Motivasyon Kuramı}

Yaşam Boyu Gelişimde Motivasyon Kuramı'na göre başarılı bir gelişim ancak bireylerin yaşam süresince kontrolü en üst düzeyde gerçekleştirmeleriyle mümkündür (Heckhausen ve 
Schulz, 1993; 1995; Heckhausen ve ark., 2010; Schulz ve Heckhausen, 1996). Bu kurama göre kontrol, bireylerin yaşamlarındaki önemli olayları mevcut koşullar çerçevesinde kontrol edebilme becerileri şeklinde tanımlanmaktadır. Bununla birlikte ilgili kavram ilk olarak Rothbaum, Weisz ve Snyder (1982) tarafından iki ayrı süreç olarak ele alınmıştır. Bu süreçlerden ilki birincil kontrol, diğeri ise ikincil kontroldür. Birincil kontrol bireylerin kendi istek ve ihtiyaçlarına uygun biçimde çevrelerini değiştirme çabalarına işaret etmektedir. İkincil kontrol ise bireylerin seçtikleri hedefi, hedefe ilişkin beklentilerini ve hedefe ilişkin yüklemelerini değiştirmeleri olarak tanımlanmaktadır. Yaşam Boyu Gelişimde Motivasyon Kuramı'na (Heckhausen ve ark., 2010) göre birincil kontrol insan davranışı için temel güdüleyici bir güçtür. Birincil kontrolün çocukluk dönemi boyunca arttı̆̆ı, orta yaşta en yüksek değerine ulaştığı ve ileri yaşla birlikte de gerilediği bilinmektedir. İkincil kontrol ise erken çocukluk döneminde çocuk yetersizlik duygusuyla ilk karşılaştığında gelişmeye başlar, okul yılları, ergenlik, genç ve orta yetişkinlik dönemi boyunca gelişmeye devam eder. Artan yaşla birlikte birey biyolojik ve sosyal sınırlamalarla daha fazla karşılaştıkça bu kontrole duyulan ihtiyaç artar (Schulz ve Heckhausen, 1996). Yaşam süresince hem birincil hem de ikincil kontrol, bireyin gelişimini en iyi hale getirebilmek amacıyla birlikte çalışmaya devam eder (Heckhausen ve Schulz, 1995; Heckhausen ve ark., 2010; Schulz ve Heckhausen, 1996).

Birincil ve ikincil kontrolün yanı sıra kuram kapsamında önerilen model insan davranışındaki çeşitlilikten kaynaklı iki temel gereksinim olan seçicilik ve başarısızlığın ödünlenmesini içermektedir (Heckhausen ve Schulz, 1993; 1995; Heckhausen, 1999; Schulz ve Heckhausen, 1996). Gereksinimlerden ilki olan seçicilik, insanın yaşamı süresince pek çok seçenek arasından kendi yaşamı için anlamlı hedeflere yönelmesi ve belirlediği bu hedefe alternatif olan diğer seçeneklere karşı seçimini koruyabilmesidir. Diğer bir gereksinim olan başarısızlığın ödünlenmesi ise başarısızlık durumuyla veya yaşla birlikte ortaya çıkan kayıplarla baş etmek amacıyla bireylerin bazı stratejilere yönelmeleri olarak kavramsallaştırılabilir (Heckhausen, 1999). Kısacası, model hem birincil ve ikincil kontrolü hem de seçicilik ve başarısızlığın ödünlenmesini içermektedir. Bu kapsamda dört farklı kontrol stratejisi tanımlanmıştır. Birincil ve ikincil kontrolün yönetimindeki seçme davranışı sırasıyla seçici birincil ve seçici ikincil kontrol, seçme işleminin başarısız olduğu durumdaki ödünleme davranışı ise sırasıyla ödünleyici birincil ve ödünleyici ikincil kontrol olarak adlandırılmıştır (Heckhausen, 1999; Heckhausen ve ark., 2010).

Modelde yer alan süreçlerden ilki olan seçici birincil kontrol belirlenen bir hedefe ulaşmak için yapılan yatırımı ifade eder. Zaman ve çaba harcama, yeteneğe yatırım yap- 
ma, hedefe ulaşmak için gerekli becerileri geliştirmeye çalışma ve zorluklarla mücadele etme bu sürece örnek olarak verilebilir. Seçici ikincil kontrol ise seçilen hedefin değerinin yükseltilmesini, rekabet halindeki diğer alternatiflerin ise değerinin düşürülmesini içerir. Birey bir hedefi elde etmenin olumlu yönlerini hayal edebilir veya hedefe ulaşmaya ilişkin kontrol algısını yükseltebilir. Diğer bir strateji olan ödünleyici birincil kontrol hedefe ulaşmak için dışsal kaynakların kullanılmasını içerir. Başkalarından tavsiye ve yardım isteme bu sürece örnek verilebilir. Dışsal yardımın yalnızca çevredeki diğer bireyler tarafindan sağlanması gerekmemektedir. Örneğin, ileri yaştaki bir birey işitme cihazı kullanmaya başlayarak teknik anlamda bir yardım da alabilir ve işlevselliğini optimal düzeye getirmeyi amaçlayabilir. Bir problemin çözümü için alışılmışın dışında yollar arama da bu süreç kapsamında değerlendirilmektedir. Sözü edilen üç strateji de bireylerin hedefleriyle olan bağlarının sürdürülmesine yardım eder. Ödünleyici ikincil kontrol ise ulaşılmas1 güç olan hedefin değerini azaltmayı, olası diğer alternatiflerin ise değerini arttırmayı içerir. Nedensel yüklemeler yapma ve kendisinden daha kötü durumda olan kişilerle kendi durumunu kıyaslama gibi benliği koruyucu stratejilere işaret eder (Heckhausen, 1999; Heckhausen ve ark., 2010; Schulz ve Heckhausen, 1996). Eğitim yaşamıly ilgili hedefine ulaşmaya çalışan bir birey, üniversite sınavında istediği bölüme yerleşebilmek amacıyla zamanının önemli bir kısmını çalışmaya ayırabilir (seçici birincil kontrol); bu başarıyı elde ettiğinde sahip olacağı olumlu sonuçları hayal ederek kendisiyle gurur duyabilir (seçici ikincil kontrol); seçtiği meslekten kişilerle fikir alışverişinde bulunabilir veya tercihleriyle ilgili rehberlik servisinden uzman kişilerle görüşebilir (ödünleyici birincil kontrol). Birey zamanla belirlediği bu hedeften uzaklaşabilir. Bu noktada elde edilmesi güç hedef yerine yeni alternatifler arayabilir veya kendinden daha kötü durumda olan kişilerle kendi durumunu kıyaslayarak benliğini koruyucu stratejileri devreye sokabilir (ödünleyici ikincil kontrol). Modelde yer alan ve tüm bu süreçlerin etkili bir biçimde kullanılmasını sağlayan üst düzey süreç ise optimizasyondur. Optimizasyon süreci kapsamında bireyler var olan firsatlar ve sınırlamalar çerçevesinde aynı zamanda içinde bulundukları gelişimsel dönemin gereklerini de dikkate alarak seçim yaparlar. Optimizasyon ayrıca modelde sözü edilen birincil kontrolün uzun vadede sürdürülmesine de katkıda bulunur (Heckhausen, 1999; Heckhausen ve ark., 2010; Schulz ve Heckhausen, 1996).

Sözü edilen süreçlerin başarılı gelişimin pek çok göstergesiyle ilişkili olduğu ortaya konulmuştur. Çalışmaların önemli bir bölümü yetişkinlik dönemindeki bireylerle yürütülmüştür (örn., Dunne ve ark., 2011; Haverstock, Ruthig ve Chipperfield, 2019; Jobin ve 
Wrosch, 2016; Schilling ve ark., 2016; Versey, 2015; Wrosch, Schulz ve Heckhausen, 2002). Demans hastası ileri yetişkinlere bakım veren bireylerde kontrol stratejilerinin kullanımı ile iyilik hali arasındaki ilişkilerin incelendiği bir çalışmada ikincil kontrol stratejisi kapsamında ele alınan pozitif yeniden değerlendirmenin (örn., yaşanan bir güçlüğün olumlu taraflarına odaklanma) bireylerin iyilik hallerine olumlu yönde katkı yapt1ğ1 ortaya konmuştur (Haverstock ve ark., 2019). Bununla birlikle, genç bireylerle yürütülen çalışmalar da bulunmaktadır (örn., Hamm, Perry, Chipperfield, Heckhausen ve Parker, 2016; Hamm ve ark., 2013; Heckhausen, Chang, Greenberger ve Chen, 2013; Russell ve Anderson, 2018; Shane ve Heckhausen, 2016). Örneğin, kontrol stratejileri ile akademik başarı arasındaki ilişkilerin incelendiği çalışmanın sonuçları, önemli bir hedefe ulaşma sürecinde hedefle olan bağın sürdürülmesine yardımcı bir strateji olan seçici ikincil kontrol stratejisinin, seçici birincil kontrolün kullanımını arttırdığına ve bu durumun da liseden üniversiteye geçiş sürecindeki bireylerin akademik başarılarına olumlu yönde katkı yaptığına işaret etmektedir (Hamm ve ark., 2013). Buna göre bireyler özellikle kendilerini zorlayacak geçiş dönemlerinde (liseden üniversiteye geçiş gibi) hedefle olan motivasyonel bağlarını sürdürdüklerinde (seçici ikincil kontrol) aktif olarak hedefin peşinden koşmaya devam edebilirler (seçici birincil kontrol). Bu durum da onların akademik başarılarını olumlu yönde etkileyebilir. Bir başka çalışma kapsamında ise üniversiteden iş yaşamına geçiş sürecinde kariyer hedefleri, kontrol stratejileri ve kontrole ilişkin inançlar arasındaki ilişkiler incelenmiştir (Shane ve Heckhausen, 2016). Elde edilen sonuçlar, hedefe ulaşmanın kendi kontrolleri dışındaki faktörlere (örn., şans, ayrıcalık) dayandığını düşünmeleri durumunda bireylerin kariyerleriyle ilişkili hedeflerinden daha fazla uzaklaştıklarına ve hedeflerini daha değersiz olarak değerlendirdiklerine işaret etmektedir. Buna karşılık, çaba ve yetenek gibi faktörlere bağlı olduğunu düşünmeleri durumunda ise bireylerin hedeflerine daha fazla önem verdikleri ve bu durumun hedefin elde edilmesini kolaylaştırdığı ortaya konulmuştur. Sonuçlar kontrole ilişkin inançlar, çaba harcama ve hedefe ulaşma arasındaki ilişkinin geçiş dönemlerinde özellikle önemli olduğuna ve farklı sonuçlara yol açabileceğine işaret etmektedir (Shane ve Heckhausen, 2016). Özetlenen araştırma bulguları, sözü edilen süreçlerin bireylerin yaşamlarına nasıl yön verdiklerini açıklamada kritik bir öneme sahip olduklarına işaret emektedir.

Yukarıdaki bilgiler 1şı̆̆ında çalışmanın temel amacı Yaşam Boyu Gelişimde Motivasyon Kuramı (Heckhausen ve ark., 2010) çerçevesinde genç bireylerin belirledikleri bir hedefe ulaşma sürecinde başvurdukları kontrol stratejilerinin neler olduğunu incele- 
mektir. Çalışma kapsamında ilk olarak bireylerin bir önceki gelişim dönemine (liseye devam ettikleri veya üniversite eğitimi aldıkları yıllar) ilişkin belirledikleri hedefler bağlamında başvurdukları stratejiler geriye dönük olarak incelenmiştir. Böylelikle modelde öne sürülen stratejilerin sözü edilen gelişim döneminde nasıl temsil edildiğinin ortaya konması amaçlanmıştır. Örneğin, üniversite sınavına hazırlık sürecindeki bir öğrencinin dershaneye gitmesi veya zorlandığı konuyla ilgili uzmanlardan yardım alması ödünleyici birincil kontrol stratejisine karşılık gelen davranışları yansıtmaktadır. Bu inceleme sonucunda oldukça soyut düzeyde ele alınan kavramların günlük yaşamdaki uygulamalarını görebilmenin mümkün olacağı düşünülmüştür. Çalışma kapsamında ikinci olarak daha genel ve varsayımsal durumlar üzerinden bireylerin tercih ettikleri kontrol stratejileri incelenmiştir. Bireylerin hem kendi deneyimlerinin hem de varsayımsal durumlar üzerinden başvurdukları stratejilerin incelenmesi, bu stratejilerin bütüncül bir bakış açısıyla değerlendirilmesine olanak sağlayacaktır. Böylelikle elde edilen bulguların ne ölçüde örtüştüğü ortaya konmuş olacaktır. Modelin temel önermeleri doğrultusunda, genç bireylerin ikincil kontrol stratejileri yerine birincil kontrol stratejilerine daha fazla başvurmaları beklenmektedir. Araştırma kapsamında ayrıca bir önceki gelişim döneminde belirlenen spesifik hedefle ilişkili olarak yakın çevredeki farklı bireylerden algılanan destek düzeylerinin de geriye dönük olarak incelenmesi amaçlanmıştır.

\section{YÖNTEM}

\section{Katılımcilar}

Çalışmanın örneklemi 214'ü (\%54) kadın, 182'si (\%46) erkek olmak üzere toplam 396 katılımcıdan oluşmaktadır. Katılımcılara amaca uygun örnekleme yöntemi ile ulaŞılmıştır. Liseyi bitirmiş ve/veya üniversite sınavına hazırlanan bireyler ile lisans ve lisansüstü öğrencileri ve farklı iş yerlerinde çalışan bireyler (örn., üniversitelerin akademik ve idari birimleri) araştırmanın örneklemini oluşturmaktadır. Katılımcıların ortalama yaşı $23.92(S S=3.80)$ olup yaş dağılımları 18 ile 30 arasında değişmektedir. Araştırmaya katılan kişilerin \%46’sı ön lisans öğrencisi-mezunu veya lisans öğrencisi olduklarını, \%48'i ise lisans mezunu, yüksek lisans ve doktora öğrencisi veya mezunu olduklarını belirtmişlerdir. Lise mezunlarının oranı ise \%6'dır. Ayrıca katılımcıların \%51'i şu an bir işte çalışmadıklarını belirtmişlerdir. Genç bireylerin \%37'si arkadaşlarıyla birlikte evde veya yurtta kaldıklarını, \%33'ü anne, baba ve kardeşleriyle, \%17'si ise eşleri ve çocuklarıyla yaşadıklarını ifade etmiştir. Diğer bireyler (\%13) ise tek başlarına, kız-erkek arkadaşlarıyla veya akrabalarının yanında yaşadıklarını belirtmişlerdir. 


\section{Veri Toplama Araçları}

Kişisel Bilgi Formu. Bu formda, katılımcıların yaşı, cinsiyeti, eğitim durumu ve gelir düzeyi gibi demografik bilgiler yer almıştır.

Kontrol Stratejileri. Araştırma kapsamında bir hedefe ulaşma sürecinde bir engel ya da başarısızlıkla karşılaşılması durumunda başvurulan kontrol stratejilerinin neler olduğunun geriye dönük olarak belirlenebilmesi amacıyla katılımcılara açık uçlu bir soru yöneltilmiştir. Öncelikle katılımcılardan lise veya üniversite yıllarını düşünmeleri ve o yıllarda kendileri için belirlemiş oldukları hedefleri hatırlamaları istenmiştir. Bu kapsamda şu yönerge verilmiştir: "Şimdi size geçmiş yıllarda kendiniz için belirlemiş olduğunuz hedeflerinizle ilgili bazı sorular soracă̆ız. Ĕ̆er 18 ile 24 yaşları arasındaysanız yaşamınızın 14 ile 17 yaşları arasına karşılık gelen yaşam dönemini, bir başka ifadeyle, lise eğitimi aldığınız yılları düşününüz. Eğer 25 ile 30 yaşları arasındaysanız yaşamınızın 18 ile 24 yaşları arasına karşılık gelen yaşam dönemini, bir başka ifadeyle, liseden mezun olduktan sonraki veya üniversite eğitimi aldığınız yılları düşününüz. Yaşamınızın bu döneminde seçtiğiniz en önemli hedefiniz neydi?”. Katılımcıların geçmişte belirledikleri hedefe ilişkin bazı değerlendirmeler ("Bu hedefiniz gerçekleşti mi?, Bu hedefe ulaşmak için ne kadar çaba harcadınız?" vb.) yapmalarının ardından kendilerine "Bu hedefe ulaşma sürecinde bir engel veya başarısızlıkla karşılaştıysanız bu durumun üstesinden gelmek için neler yaptını//hangi yolları denediniz? Kısaca açıklayınız." sorusu yöneltilmiştir. Araştırma kapsamında strateji kullanımına ilişkin ilk inceleme katılımcıların açık uçlu bu soruya verdikleri cevaplar üzerinden yapılmıştır.

Optimizasyon ve Kontrol Stratejileri Ölçeği. Heckhausen ve Schulz (1993; 1995) tarafından önerilen model çerçevesinde geliştirilen ve orijinal adı Optimization in Primary and Secondary Control (OPS) Scale olan ölçek toplam 44 maddeden oluşmaktadır. Maddeler (örn., "Bir hedefim olduğunda, onu elde edebilmek amaciyla gerekli becerileri geliştirmek için çok çalışmaya hazırımdır.") beşli Likert tipi ölçek ( 1 = "Hiç uymuyor", 5 = “Tamamıyla uyuyor”) üzerinden cevaplandırılmıştır. Ölçek beş farklı stratejiyi ölçmektedir (Heckhausen, Schulz ve Wrosch, 1998). Bu stratejiler optimizasyon, seçici birincil kontrol, seçici ikincil kontrol, ödünleyici birincil kontrol ve ödünleyici ikincil kontroldür. Cronbach Alfa iç tutarlık katsayıları alt boyutlar için .79 ile .81 arasında değişmektedir (Heckhausen ve ark., 1998). Ölçeğin Türkiye örneklemine uyarlama çalışması Uçanok (2001; 2002a) tarafından yapılmıştır. Elde edilen sonuçlar alt ölçeklerin Cronbach Alfa iç tutarlık katsayılarının .65 ile .86 arasında değişstiğine işaret 
etmektedir. Bu çalışma kapsamında ise alt ölçeklerin Cronbach Alfa iç tutarlık katsayıları optimizasyon için .78, seçici birincil kontrol için .87 ve seçici ikincil kontrol için .78 olarak bulunmuştur. Ödünleyici birincil kontrol ve ödünleyici ikincil kontrol için ise Cronbach Alfa iç tutarlık katsayıları sırasıyla .81 ve .59' dur. Araştırma kapsamında strateji kullanımına ilişkin ikinci inceleme ise sözü edilen ölçüm aracından elde edilen toplam puanlar üzerinden yapılmıştır.

Hedefe İlişkin Algılanan Destek. Çalışma kapsamında katılımcılar geçmişte belirledikleri hedefleriyle ilgili olarak yakın çevrelerindeki bireylerin kendilerine ne ölçüde destek olduklarını geriye dönük olarak değerlendirmişlerdir. Buna ilişkin olarak katılımcılara "Hedefinizle ilgili yakın çevrenizdeki kişilerin (anne, baba, kardeş, akran, eş/kız veya erkek arkadaş) size ne ölçüde destek olduklarını düşünüyorsunuz?” sorusu yöneltilmiş ve katılımcılardan her bir bireyle ilgili ayrı ayrı değerlendirme yapmaları yedili Likert tipi skala (1 = "Hiç destek olmadılar”, 7 = "Çok destek oldular”) üzerinden istenmiştir.

\section{İşlem}

Uygulama öncesinde Üniversitenin Etik Komisyonundan gerekli izinler alınmıştır. Uygulamalar bireysel olarak gerçekleştirilmiştir. Tüm katılımcıların ölçekleri kendileri için uygun olan bir zamanda ve ortamda, olabildiğince zaman baskısı hissetmeden yanıtlamaları sağlanmaya çalışılmıştır. Uygulama formu bir zarf içerisinde katılımcılara verilmiş ve katılımcılardan doldurdukları formları yaklaşık bir hafta içerisinde kapalı bir zarfla araştırmacıya teslim etmeleri istenmiştir. Araştırmaya katılım gönüllülük esasina dayanmaktadir.

\section{Veri Analizi}

Kontrol stratejilerine ilişkin nitel analiz sürecinde katılımcıların açık uçlu soruya verdikleri yanıtlar ilk olarak Excel dosyasına, sonrasında ise MAXQDA 11 programına aktarılmıştır. Kontrol stratejilerine ilişkin alan yazın kodlama süreci öncesinde araştırmacılar tarafından tekrar gözden geçirilmiştir. Yaşam Boyu Gelişimde Motivasyon Kuramı (Heckhausen ve ark., 2010) kapsamında öne sürülen stratejiler (seçici birincil ve ikincil kontrol ile ödünleyici birincil ve ikincil kontrol) temel alınarak katılımcıların kendilerine yöneltilen açık uçlu soruya verdikleri yanıtlar incelenmiştir. $\mathrm{Bu}$ inceleme doğrultusunda temel bazı kategorilerin var olup olmadığı değerlendirilmiş ve kodlama işleminin tümü sorumlu araştırmacı tarafından gerçekleştirilmiştir. Yaş, cinsiyet, eğitim durumu gibi demografik pek çok özellik de kodlama işlemi sırasında göz önünde bulun- 
durulmuştur. Kontrol stratejileri açısından temel kategoriler tümdengelim yaklaşımına uygun olarak belirlenmiştir. Temel kategorilere kodlama işlemi bittikten sonra kodlama içerikleri kontrol edilmiştir. Sonraki adımda ise açık uçlu soruya verilen benzer yanıtlar bir araya getirilerek alt kategoriler tümevarım yaklaşımına uygun olarak oluşturulmuştur. Alt kategorilerin oluşturulması, kodlama içeriklerinin kontrolü ve gerekli revizyonların yapılması her iki araştırmacının ortak görüşüyle gerçekleştirilmiştir. Temel kategoriler alan yazın bilgilerinden yararlanılarak belirlenirken, kodlar tamamıyla katılımcıların verdikleri cevaplar dikkate alınarak oluşturulmuştur. Hem tümevarım hem de tümdengelim yaklaşımları temel alınarak niteliksel verilerin analizi gerçekleştirilmiştir (örn., Varjas, Nastasi, Moore ve Jayasena, 2005). Analizin düz-doğrusal değil de dairesel bir sürece sahip olmasının, kategoriler arasında hareket ederek esnek bir biçimde ilerlemesinin ve araştırmacıya her türlü değişikliği yapabilme imkanı sağlamasının kavramların (kategorilerin) geçerliğini arttırdığı öne sürülmekte (Dey, 1993; akt., Kuş, 2006) ve kullanılan analiz programı da bu süreci destekleyerek analizi sistematik (örn., kodlama içeriklerine anında erişme) kılmaktadır (Kuş, 2006).

Kodlama işlemi sırasında katılımcıların bir kısmının birden fazla kategoride strateji belirttikleri görülmüştür. Örneğin, bir katılımcı kendisine yöneltilen açık uçlu soruya “Üniversite sınavını ilk senemde kazanamadım. Ve tekrar denedim. Daha çok ders çalıştım. Yardım alabileceğim herkesten yardım aldım." şeklinde cevap vermiştir. Bu durumda her bir ifade ilgili kategoriye kodlanmıştır. Bunun sebebi bireylerin birden fazla stratejiyi eş zamanlı olarak kullanabilmeleridir. Söz konusu durumda "Ve tekrar denedim” ile "Daha çok ders çalıştım” ifadeleri seçici birincil kontrol; "Yardım alabileceğim herkesten yardım aldım" ifadesi ise ödünleyici birincil kontrol kapsamında sınıflandırılmıştır. Temel kategorilere kodlama işleminin bitmesinin ardından ise ifadeler ilgili alt kategorilere kodlanmıştır. Bu durumda “Ve tekrar denedim” ifadesi tekrardan deneme/ mücadele etme; "Daha çok ders çalıştım” ifadesi ise zamana ve çabaya yatırım yapma alt kategorisine kodlanmıştır. İki ifade de aynı strateji kapsamında değerlendirilmekte, ancak ilgili stratejinin farklı yönlerine işaret etmektedir. Son ifade olan "Yardım alabileceğim herkesten yardım aldım" ifadesi ise diğer insanlardan yardım, tavsiye, öğ̈ isteme alt kategorisine kodlanmıştır. Böylelikle katılımcılar tarafından ifade edilen her bir strateji ilgili temel ve alt kategoriye kodlanmıştır.

Kontrol stratejilerine ilişkin nicel analiz kapsamında ise katılımcıların başvurdukları stratejilerin neler olduğu tek faktörde tekrar ölçümlü ANOVA ile değerlendirilmiştir. 
Analiz öncesinde Yaşam Boyu Gelişimde Motivasyon Kuramı bileşenleri arasındaki korelasyonlar Pearson Momentler Çarpımı korelasyon tekniği kullanılarak hesaplanmıştır.

Yakın çevrede yer alan kişilerden algılanan destek açısından anlamlı farklılıkların olup olmadığı Friedman Varyans Analizi ile incelenmiştir. İkili karşılaştırmalar için Wilcoxon Testi kullanılmış ve Tip 1 hatayı kontrol etmek amacıyla Bonferroni düzeltmesi yapılmıştır. Verilerin analizinde IBM SPSS 23 programı kullanılmıştır.

\section{BULGULAR}

\section{Kontrol Stratejilerine İlişkin Nitel Analiz Sonuçları}

Katılımcıların \%75'inin "Bu hedefe ulaşma sürecinde bir engel veya başarısızlıkla karşılaştıysanız bu durumun üstesinden gelmek için neler yaptını/hangi yolları denediniz? Kısaca açıklayınız.” sorusunu yanıtladıkları görülmüştür. Bu soruya yanıt veren katılımcıların yaş ortalaması 23.58 'dir $(S S=3.76)$ ve \%8.8'i bu süreçte herhangi bir engel ya da başarısızlıkla karşılaşmadıklarını ifade etmiştir. Katılımcıların tümü geçmişe dönük olarak hedef belirtmişlerdir. Bununla birlikte ilgili soruya yanıt vermeyen katılımcılar belirledikleri bu hedefe ulaşma sürecinde herhangi bir engelle veya zorlukla karşılaşmamış olabilirler veya karşılaşmış olmalarına rağmen bu durumun üstesinden gelmek için herhangi bir yol denememiş olabilirler. Soruya yanıt veren ve vermeyen katılımcıların demografik özelliklerine ilişkin yüzdeler Tablo 1'de sunulmuştur.

Tablo 1. İlgili Soruya Yanıt Veren ve Vermeyen Katılımcıların Demografik Özelliklerine İlişkin Yüzdeler

\begin{tabular}{lcc}
\hline & Yanıt Verenler (\%) & Yanıt Vermeyenler (\%) \\
\hline Cinsiyet & 57 & 45 \\
Kadın & 43 & 55 \\
Erkek & & \\
Ĕ̆itim Durumu & 6.4 & 5 \\
Lise Mezunu & 3 & 5 \\
Ön Lisans Öğrencisi ve Mezunu & 45.6 & 34 \\
Lisans Öğrencisi & 18.6 & 17 \\
Lisans Mezunu & 11.8 & 10 \\
Yüksek Lisans Öğrencisi & 3.7 & 10 \\
Yüksek Lisans Mezunu & - & 18 \\
Doktora Öğrencisi & 10.8 & 1 \\
Doktora Mezunu & & \\
Çalışma Durumu & 45 & 62 \\
Çalışıor & 55 & 38 \\
Çalışmıyor & & \\
& &
\end{tabular}


Tablo 1'den de takip edilebileceği gibi açık uçlu soruya yanıt veren katılımcıların \%57'si kadın, \%43’ü erkektir. Yanıt vermeyen katılımciların ise \%45'inin kadın, \%55'inin erkek olduğu görülmüştür. İlgili soruya yanıt veren ve vermeyen katılımcıların önemli bir bölümü üniversite öğrencisi olduklarını (sırasıyla \%46 ve \%34) ifade etmişlerdir. Çalışma durumu açısından bakıldığında ise ilgili soruya yanıt veren katılımcıların \%55'inin, soruya yanıt vermeyen katılımcıların ise \%38'inin şu an herhangi bir işte çalışmadıkları görülmüştür.

Hedefe ulaşma sürecinde kullanılan kontrol stratejileri yedi temel başlık altında ele alınmıştır. Bu kategoriler belirlenirken Yaşam Boyu Gelişimde Motivasyon Kuramı (Heckhausen ve ark., 2010) kapsamında öne sürülen stratejiler referans alınarak seçici birincil kontrol, ödünleyici birincil kontrol, seçici ikincil kontrol ve ödünleyici ikincil kontrol olarak dört kategori tanımlanmıştır. Bu dört kategoriye uymayan yanıtlar ise herhangi bir yol denememe/hiçbir şey yapmama, diğer ve işlevsel olmayan stratejiler kategorilerine kodlanmıştır (Bkz. Şekil 1).

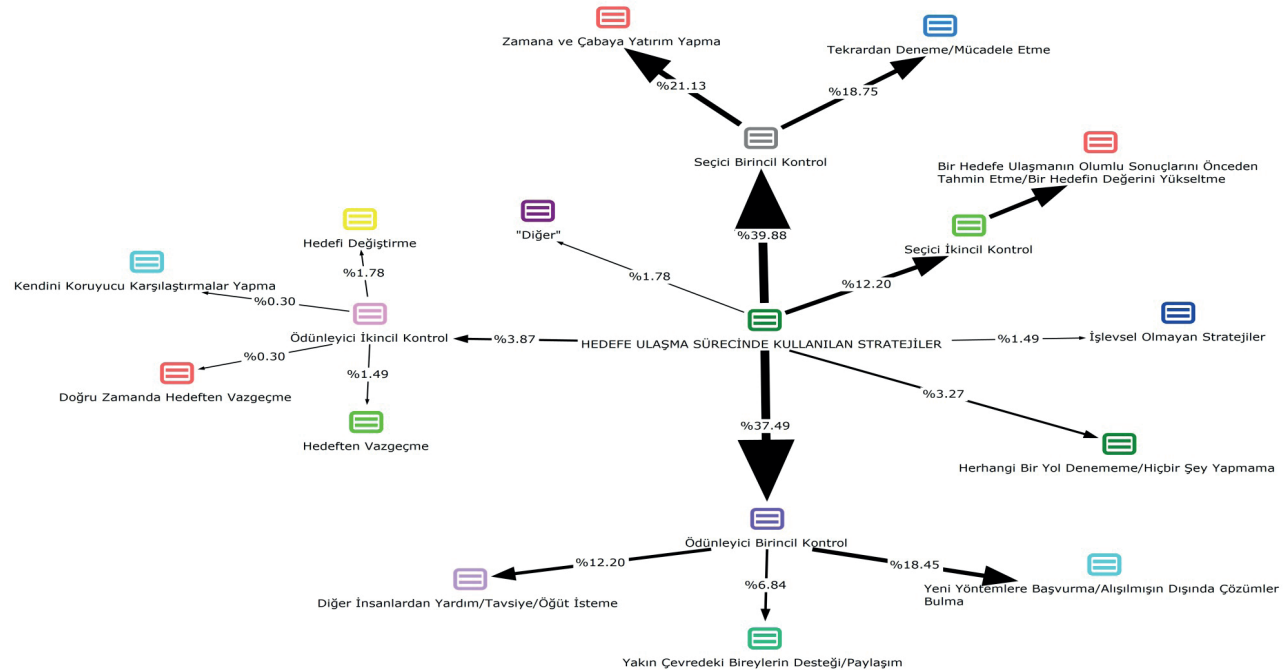

Şekil 1. Lise ve Üniversite Döneminde Belirlenen Hedefe Ulaşma Sürecinde Başvurulan Kontrol Stratejilerine İlişkin Yüzdeler

Şekil 1'den de takip edilebileceği gibi niteliksel veri analizi sonucunda, katılımcılar tarafından verilen cevapların önemli bir çoğunluğunun seçici birincil kontrol (\%39.88) ve ödünleyici birincil kontrol (\%37.49) stratejileri kapsamında değerlendirilebileceği görülmüştür. Belirlenen bir hedefe ulaşmak için yapılan yatırımı ifade eden seçici birin- 
cil kontrol (1) zamana ve çabaya yatırım yapma (\%21.13) ve (2) tekrardan deneme/mücadele etme (\%18.75) olmak üzere iki alt kategoriden oluşmaktadır. Zamana ve çabaya yatırım yapma bağlamında genç bireyler "daha çok çalıştım”, “çalışma saatlerimi arttırdım”, “daha çok test çözdüm” ve "YGS kötü geçtiğinde LYS'ye daha fazla çalıştım” vb. ifadeler kullanmışlardır. Tekrardan deneme/mücadele etme bağlamında ise bireyler “tekrar denedim”, “ilk sene olmad, tekrar hazırlandım”, "pes etmedim” ve "vazgeçmedim” ifadelerini kullanmışlardır (Bkz. Tablo 2).

Bireylerin sıklıkla başvurdukları bir diğer strateji olan ödünleyici birincil kontrol ise (1) yeni yöntemlere başvurma/alışılmışın dışında çözümler bulma (\%18.45), (2) diğer insanlardan yardım/tavsiye/ögüt isteme (\%12.20) ve (3) yakın çevredeki bireylerin desteği/paylaşım (\%6.84) olmak üzere üç alt kategoriden oluşmaktadır. Yeni yöntemlere başvurma/alışılmışın dışında çözümler bulma bağlamında genç bireyler "yeni yollar denedim”, “dershaneye gittim”, "başarısızlıklarımı gözden geçirdim ve yeni planlar yaptım” ve “çalıştığım işi bırakıp ders çalıştım” vb. ifadeler kullanmışlardır. Diğer insanlardan yardım/tavsiye/ögüt isteme bağlamında "yardım aldım”, "aynı problemi yaşayan insanlarla iletişime geçtim, görüşlerini aldım”, “ailemle paylaşıp soruna birlikte çözüm aradım" ve "hocalarım ve arkadaşlarımdan yardım aldım” ifadelerini kullanmışlardır. İlgili kategoride yakın çevredeki bireylerin desteği/paylaşım bağlamında ise "çevremden destek aldım", "stresi yenmek için ailem ve hocalarımdan destek aldım” ve "ailem, arkadaşlarım motive ettiler” vb. ifadeler kullanılmıştır (Bkz. Tablo 2).

Analiz sonucunda birincil kontrol stratejilerini seçici ikincil kontrol stratejisinin (\%12.20) izlediği görülmüştür. Sözü edilen strateji bağlamında tek bir alt kategori oluşturulmuştur. Bir hedefe ulaşmanın olumlu sonuçlarını önceden tahmin etme/bir hedefin değerini yükseltme bağlamında katılımcılar "kendimi motive etmeye çalıştım”, "hedefime ulaştı̆̆ımda hissettiğim gururu ve mutluluğu düşündüm”, "başaracağıma inanıp devam ettim” ve "bunu ne için istediğimi hatırlayarak kendimi motive ettim” vb. ifadeler kullanmışlardır (Bkz. Tablo 2).

Yaşam Boyu Gelişimde Motivasyon Kuramı (Heckhausen ve ark., 2010) kapsamında öne sürülen stratejiler referans alınarak oluşturulan son kategori ise ödünleyici ikincil kontroldür. Katılımcılar tarafından en az başvurulan kontrol stratejisinin ödünleyici ikincil kontrol stratejisi (\%3.87) olduğu görülmüştür. Ödünleyici ikincil kontrol stratejisi ise (1) hedefi değiştirme (\%1.78), (2) hedeften vazgeçme (\%1.49), (3) kendini koruyucu sos- 
yal karşılaştırmalar yapma (\%0.30) ve (4) doğru zamanda hedeften vazgeçme $(\% 0.30)$ olmak üzere dört alt kategoriden oluşmaktadır. Hedefi değiştirme bağlamında gençlerin “hedefe giden yolda meslek değiştirdim” ve "yapabileceğim çok seçenek olmadiğ için istediğim ikinci bölümü tercih ettim”; hedeften vazgeçme bağlamında "kabullendim”; kendini koruyucu sosyal karşılaştırmalar yapma bağlamında "benden kötü olanları düşünür iyi olana yaklaşmak için çabalarım” ve son olarak doğru zamanda hedeften vazgeçme bağlamında ise "tekrar tekrar denedim, ama en sonunda vazgeçtim, vazgeçmem gereken zamanda vazgeçtim” gibi ifadeler kullandıkları görülmüştür (Bkz. Tablo 2).

Araştırma kapsamında tanımlanan üç yeni kategori ise herhangi bir yol denememel hiçbir şey yapmama (\%3.27) (örn., "herhangi bir yol denemedim”, “herhangi bir şey yapmadım”), diğer (\%1.78) (örn., “engele bağll”) ve işlevsel olmayan stratejilerdir (\%1.49) (örn., “yokmuş gibi davrandım”) (Bkz. Tablo 2).

Tablo 2. Kontrol Stratejilerine İlişkin Temel ve Alt Kategoriler ile Kodlar, Örnek İfadeler ve Frekans Değerleri

\section{Temel Kategori: Seçici Birincil Kontrol}

Alt Kategori: Zamana ve Çabaya Yatırım Yapma

\begin{tabular}{|c|c|c|}
\hline Kodlar & Örnek İfadeler & Frekans \\
\hline Çalışmak & $\begin{array}{l}\text { "Başarısızlıkları çalışarak atlattım ve üstesinden } \\
\text { geldim" }\end{array}$ & 5 \\
\hline Çok çalışmak & "Çok çalıştım" & 8 \\
\hline Daha çok/fazla çalışmak & "Daha fazla çalışmaya yöneldim" & 38 \\
\hline Bir sonraki adımda daha fazla çalışma & $\begin{array}{l}\text { "YGS kötü geçtiğinde LYS'ye daha fazla } \\
\text { çalıştım" }\end{array}$ & 2 \\
\hline Ders çalışmak/sınavlara çalışmak/test çözmek & "Daha çok ders çalıştım" & 7 \\
\hline $\begin{array}{l}\text { İlk denemede olmadığında ikincisinde daha } \\
\text { fazla çaba harcama }\end{array}$ & $\begin{array}{l}\text { "İlk sene kazanamadı̆̆ım üniversiteyi ikinci sene } \\
\text { daha fazla çalışarak kazanmayı başardım" }\end{array}$ & 3 \\
\hline Eksik yönlerini telafi etmek için çalışmak & $\begin{array}{l}\text { "Eksik olduğum derslere daha fazla önem } \\
\text { vererek bașarl sağladım" }\end{array}$ & 8 \\
\hline
\end{tabular}

Alt Kategori: Tekrardan Deneme/Mücadele

Etme

\begin{tabular}{lll}
\hline Kodlar & Örnek İfadeler & Frekans \\
\hline Tekrardan deneme & "Tekrar denedim” & 33 \\
Denemekten vazgeçmeme & "Denemekten vazgeçmedim, yola devam ettim” & 7 \\
Pes etmemek & "Pes etmedim” & 5 \\
Yılmadan devam etmek & "Yllmadan yoluma büyük bir kararlılıkla devam 4 \\
& ettim” & 4 \\
Sorunun üzerine gitme & "Bıkmadan sorunun üzerine gittim” & 4 \\
Umutsuzluğa kapılmadan sorunun üzerine gitme "Umutsuzluğa kapılmayıp çözüm yollarl & 2
\end{tabular}


Vazgeçmeme/vazgeçmeden hedefe ulaşmak için "Vazgeçmedim” $\quad 6$ çalışma

Mücadele etme/kendiyle mücadele etme "Mücadele ettim" 2

Temel Kategori: Ödünleyici Birincil Kontrol

Alt Kategori: Diğer İnsanlardan Yardım, Tavsiye, Öğüt İsteme

\begin{tabular}{lll}
\hline Kodlar & Örnek İfadeler & Frekans \\
\hline $\begin{array}{l}\text { Profesyonel yardım almak } \\
\text { Zorluk çekilen konuda tecrübe sahibi kişilere } \\
\text { danışma/onlardan yardım alma }\end{array}$ & $\begin{array}{l}\text { "Psikolog desteği almayı kabul ettim” } \\
\text { "Benden önce denemiş ve başarmış olanlarla } \\
\text { Yakınıştum çevredeki bireylerle çözüm odaklı bir }\end{array}$ & 6 \\
araya gelme/konuşma/danışma & "Ailemle paylaşıp soruna birlikte çözüm aradım” 13 \\
Yakın çevredeki bireylerden yardım alma & "Aile, arkadaş yardımı aldım” & 6 \\
Başkalarının onu nasıl yaptığına bakma & "Örneklere bakarım” & 2 \\
Yol gösterici yayınları ve kitapları takip etme & "Çözüm için yararlanacağım kaynak aradım” & 6
\end{tabular}

\section{Alt Kategori: Yakın Çevredeki Bireylerin}

Desteği, Paylaşım

\begin{tabular}{lll}
\hline Kodlar & Örnek İfadeler & Frekans \\
\hline Destek & "Çevremin desteğiyle bu durumu atlattım” & 17 \\
Paylaşım & "Ailem ve rehber ögretmenlerimle konuşarak & 6 \\
& stresimin üstesinden geldim” &
\end{tabular}

Alt Kategori: Yeni Yöntemlere Başvurma, Alışılmışın Dışında Çözümler Bulma

\begin{tabular}{lll}
\hline Kodlar & Örnek İfadeler & Frekans \\
\hline Yeni yöntemlere başvurma & "Hedefe ulaştıracak farklı yolları denedim” & 23 \\
Somut adımlar atma & "Dershaneye gittim” & 29 \\
İmkansızlık, zamansızlık durumlarında kendi & "Kendi imkanlarımla ders çalışmak oldu” & 5 \\
başına çabalama & & \\
Konuşup ikna için çalışmak/tartışmak & "Ailem öğretmen olmamı istemediler onları ikna 5
\end{tabular}

\section{Temel Kategori: Seçici İkincil Kontrol}

\section{Alt Kategori: Bir Hedefe Ulaşmanın Olumlu \\ Sonuçlarını Önceden Tahmin Etme, Bir \\ Hedefin Değerini Yükseltme}

\begin{tabular}{lll}
\hline Kodlar & Örnek İfadeler & Frekans \\
\hline Kendini motive etme/telkinlerde bulunma & "Kendimi motive etmeye çalıştım” & 19 \\
Zihinsel olarak kendini rahatlatmak & "Kafamı dă̆ıtmaya çalıştım” & 5 \\
İnanmak & "Başaracağıma inanıp devam ettim” & 2 \\
Hırslanmak & "Hırs yaptım. Yardım almadım. İçselleştirdim. & 2 \\
Sabretmek/sabredip yolundan sapmamaya & Kazandım” & 8
\end{tabular}
gayret etmek 
Bir süre ara verme, doğru zamanı bekleme, erteleme

"Çalışmaya ara verdim. Sakinleşince devam 5 ettim" 5

\begin{tabular}{|c|c|c|}
\hline & & $41(\% 12.20)$ \\
\hline Temel Kategori: Ödünleyici İkincil Kontrol & Örnek İfadeler & Frekans \\
\hline Alt Kategori: Hedefi Değiştirme & "Hedefe giden yolda meslek değiştirdim" & $6(\% 1.78)$ \\
\hline $\begin{array}{l}\text { Alt Kategori: Kendini Koruyucu Sosyal } \\
\text { Karşılaştırmalar Yapma }\end{array}$ & $\begin{array}{l}\text { "Benden kötü olanları düşünür iyi olana } \\
\text { yaklaşmak için çabalarım” }\end{array}$ & $1(\% 0.30)$ \\
\hline $\begin{array}{l}\text { Alt Kategori: Doğru Zamanda Hedeften } \\
\text { Vazgeçme }\end{array}$ & $\begin{array}{l}\text { "Tekrar tekrar denedim. Ama en sonunda } \\
\text { vazgeçtim. Vazgeçmem gereken zamanda } \\
\text { vazgeçtim", }\end{array}$ & $1(\% 0.30)$ \\
\hline Alt Kategori: Hedeften Vazgeçme & $\begin{array}{l}\text { "Denedim, çok istemiştim ama bilinçli değildim } \\
\text { sanırım ve olmadiysa ne yapayım dedim. Üstüne } \\
\text { gitmedim" }\end{array}$ & $5(\% 1.49)$ \\
\hline \multirow[t]{2}{*}{$\begin{array}{l}\text { Temel Kategori: Herhangi Bir Yol } \\
\text { Denememe, Hiçbir Şey Yapmama }\end{array}$} & Örnek İfadeler & Frekans \\
\hline & "Herhangi bir şey yapmadım" & $11(\% 3.27)$ \\
\hline \multirow[t]{2}{*}{ Temel Kategori: İşlevsel Olmayan Stratejiler } & Örnek İfadeler & Frekans \\
\hline & "Yokmuş gibi davrandım" & $5(\% 1.49)$ \\
\hline \multirow[t]{2}{*}{ Temel Kategori: Diğer } & Örnek İfadeler & Frekans \\
\hline & "Sağllk sorunlarl yaşadım" & $6(\% 1.78)$ \\
\hline
\end{tabular}

\section{Kontrol Stratejilerine İliş̧kin Nicel Analiz Sonuçları}

Analiz öncesinde Yaşam Boyu Gelişimde Motivasyon Kuramı (Heckhausen ve ark., 2010) bileşenleri arasındaki korelasyonlar incelenmiştir. Elde edilen korelasyonların beklendik yönde pozitif ve anlamlı olduğu görülmüsstür (Bkz. Tablo 3).

Tablo 3. Stratejilerin Pearson Korelasyon Katsayıları, Ortalama ve Standart Sapma Değerleri

\begin{tabular}{|c|c|c|c|c|c|c|}
\hline & 1 & 2 & 3 & 4 & 5 & Ort. (S) \\
\hline 1. Optimizasyon & - & & & & & $3.72(.49)$ \\
\hline 2. Seçici Birincil K. & $.54 * * *$ & - & & & & $4.00(.58)$ \\
\hline 3. Ödünleyici Birincil K. & $.51 * * *$ & $.53 * * *$ & - & & & $3.81(.60)$ \\
\hline 4. Seçici İkincil K. & $.63 * * *$ & $.67 * * *$ & $.46 * * *$ & - & & $3.76(.58)$ \\
\hline 5. Ödünleyici İkincil K. & $.51 * * *$ & $.32 * * *$ & $.39 * * *$ & $.49 * * *$ & - & $3.22(.53)$ \\
\hline
\end{tabular}
$* * * p<.001$

Tek Faktörde Tekrar Ölçümlü ANOVA sonuçları bazı stratejilerin diğer stratejilere kıyasla anlamlı olarak daha az kullanıldığına işaret etmektedir. Buna göre Yaşam Boyu Gelişimde Motivasyon Kuramı (Heckhausen ve ark., 2010) bileşenlerinden ödünleyici ikincil kontrolün diğer kontrol stratejileri ve optimizasyona göre daha az kullanıldığ ortaya konulmuştur, $\left(F(3.51,1386.65)=215.82, p<.001, \eta^{2}=.35\right)$. Analiz sonucunda ayrıca, seçici birincil kontrol stratejisinin seçici ikincil kontrol ve ödünleyici birincil kontrolden daha çok kullanıldığg görülmüştür. 


\section{Hedefe İliş̧kin Algılanan Destek}

Destek kaynaklarına ilişkin sonuçlar, bireylerin hedefleriyle bağlantılı olarak anne $($ Ort. $=6.09, S S=1.54)$, baba $(O r t .=5.87, S S=1.78)$, kardeş $(O r t .=5.67, S S=1.80)$, arkadaş $($ Ort. $=5.16, S S=1.79)$ ve eş/kiz veya erkek arkadaştan $($ Ort. $=5.23, S S=1.95)$ yüksek oranda destek algıladıklarına işaret etmektedir. Friedman Varyans Analizi sonucunda, belirlenen hedefle bağlantılı olarak yakın çevredeki bireylerden algılanan destek açısından anlamlı farkl11ıklar olduğu ortaya konulmuştur $\left(X^{2}(4, N=224)=108.94, p<\right.$ .001). İkili karşılaştırma sonuçları anneden algılanan desteğin diğer tüm kaynaklardan algılanan destekten anlamlı olarak daha yüksek olduğuna işaret etmektedir. Babadan ve kardeşten algılanan destek, arkadaş ve eşten (eş/kız veya erkek arkadaş) algılanan destekten daha yüksektir. Baba ve kardeşten algılanan destek ile arkadaş ve eşten (eş/kız veya erkek arkadaş) algılanan destek arasında anlamlı farklılık bulunmamaktadır (Bkz. Tablo 4).

Tablo 4. Destek Kaynaklarına İlişkin Wilcoxon Testi İkili Karşılaştırma Sonuçları

\begin{tabular}{|c|c|c|c|c|c|}
\hline & & $N$ & Sira Ort. & $z$ & $p^{*}$ \\
\hline \multirow[t]{2}{*}{ Baba-Anne } & Negatif Siralar & 44 & 35.72 & -3.30 & .001 \\
\hline & Pozitif Siralar & 21 & 27.31 & & \\
\hline \multirow[t]{2}{*}{ Kardeş-Anne } & Negatif Siralar & 102 & 68.89 & -5.66 & .000 \\
\hline & Pozitif Siralar & 32 & 63.06 & & \\
\hline \multirow[t]{2}{*}{ Arkadaş-Anne } & Negatif Siralar & 185 & 112.32 & -9.22 & .000 \\
\hline & Pozitif Siralar & 35 & 100.87 & & \\
\hline \multirow[t]{2}{*}{ Eş-Anne } & Negatif Siralar & 101 & 68.70 & -6.28 & .000 \\
\hline & Pozitif Siralar & 29 & 54.36 & & \\
\hline \multirow[t]{2}{*}{ Kardeş-Baba } & Negatif Siralar & 86 & 61.98 & -2.53 & .012 \\
\hline & Pozitif Siralar & 44 & 72.38 & & \\
\hline \multirow[t]{2}{*}{ Arkadaş-Baba } & Negatif Siralar & 163 & 103.08 & -6.89 & .000 \\
\hline & Pozitif Sıralar & 45 & 109.64 & & \\
\hline \multirow[t]{2}{*}{ Eş- Baba } & Negatif Siralar & 87 & 65.71 & -4.01 & .000 \\
\hline & Pozitif Siralar & 40 & 60.28 & & \\
\hline \multirow[t]{2}{*}{ Arkadaş-Kardeş } & Negatif Siralar & 134 & 98.95 & -5.07 & .000 \\
\hline & Pozitif Siralar & 59 & 92.58 & & \\
\hline \multirow[t]{2}{*}{ Eş-Kardeş } & Negatif Siralar & 87 & 66.09 & -3.12 & .002 \\
\hline & Pozitif Siralar & 45 & 67.29 & & \\
\hline \multirow[t]{2}{*}{ Eş -Arkadaş } & Negatif Siralar & 48 & 58.00 & -1.12 & .263 \\
\hline & Pozitif Siralar & 64 & 55.38 & & \\
\hline
\end{tabular}

*Bonferroni düzeltmesi sonrası anlamlı olan değerler koyu renk ile gösterilmiştir.

\section{TARTIŞMA}

Alan yazında bireylerin kendi yaşamlarını şekillendirmede aktif bir rol oynadıkları öne sürülmektedir (Heckhausen, Wrosch ve Schulz, 2019). Bu kapsamda bireyler önemli gördükleri veya kendileri için anlamlı olan hedefleri elde etmek için zaman ve çaba 
harcamakta, bu hedefleri elde etmek için mücadele etmekte ve olası alternatiflerin dikkatlerini dağıtmasından kaçınmaktadır. Gösterilen bu çaba, bireye yaşamının kendi kontrolünde olduğu hissini vermektedir. Mevcut çalışmada elde edilen sonuçlar da bu görüşü desteklemekte, bireylerin belirledikleri hedeflere ulaşabilmek amaciyla yoğun bir çaba harcadıklarına, içinde bulundukları gelişimsel dönemle uyumlu bir biçimde hedefle olan bağın sürdürülmesine katkı sağlayan stratejilere sıklıkla başvurduklarına işaret etmektedir. Ayrıca, sonuçlar sözü edilen modelin temel önermeleriyle uyumlu bir örüntünün varlığına işaret etmektedir.

Araştırmanın bulguları lise veya üniversite döneminde bireylerin belirledikleri bir hedefe ulaşma sürecinde birincil kontrol stratejilerine ikincil kontrol stratejilerinden daha fazla oranda başvurduklarını göstermektedir. Niteliksel veri analizi sonucunda açık uçlu soruya verilen yanıtların önemli bir çoğunluğu (\%80’e yakını) seçici birincil kontrol ve ödünleyici birincil kontrol kapsamında sınıflandırılmıştır. Bu sonuç, genç bireyler arasında birincil kontrol stratejilerinin, ikincil kontrol stratejilerine oranla daha fazla tercih edildiği şeklinde yorumlanabilir. Çalışma kapsamında ayrıca birincil kontrol stratejilerini seçici ikincil kontrol stratejisinin (\%12) izlediği görülmüştür. Sözü edilen üç strateji de bireylerin hedefleriyle olan motivasyonel bağlarını sürdürmelerine yarayan, bir başka ifadeyle, bireylerin belirledikleri hedeflerin peşinden gitmelerine olanak sağlayan stratejiler olarak kavramsallaştırılmaktadır (Haase, Heckhausen ve Wrosch, 2013).

Niteliksel veri analizi sonucunda seçici birincil kontrolün "zamana ve çabaya yatırım yapma” ve "tekrardan deneme/mücadele etme”, ödünleyici birincil kontrolün ise "yeni yöntemlere başvurma/alışılmışın dışında çözümler bulma”, "diğer insanlardan yardım/ tavsiye/öğ̈̈t isteme" ve "yakın çevredeki bireylerin desteği/paylaşım” boyutlarıyla temsil edildiği görülmüştür. Belirtildiği üzere seçici birincil kontrol, belirlenen bir hedefin peşinden koşmak için kaynaklara yatırım yapmayı içermekte, kaynaklara yatırım ise hedefi elde etmek için zaman ve çaba harcamayı, yeni beceriler geliştirmeyi kapsamaktadır. Diğer taraftan ödünleyici birincil kontrol ise bireyin sahip olduğu kaynaklar bir hedefi elde etmek için yetersiz kaldığında devreye girmektedir. Bu durumda birey dışsal kaynaklara ihtiyaç duyabilir, çevredeki diğer bireylerden yardım ya da tavsiye isteyebilir. Bu kapsamda seçici ve ödünleyici birincil kontrolün yukarıda sözü edilen göstergelerle temsil edilmesinin modelin varsayımlarıyla oldukça tutarlı olduğu söylenebilir. Araştırma kapsamında seçici ikincil kontrol stratejisinin ise "bir hedefe ulaşmanın olumlu sonuçlarını önceden tahmin etme, bir hedefin değerini yükseltme” boyutuyla temsil edildiği gö- 
rülmüştür. Seçici ikincil kontrol seçilen hedefin değerinin yükseltilmesini, seçilmeyen alternatiflerin ise değerinin düşürülmesini içerir. Seçilen bir hedef yerine daha iyi alternatifler devreye girdiğinde veya seçilen hedef beklenmeyen engeller tarafindan kesintiye uğratıldığında bu strateji önem kazanmaktadır (Heckhausen, 1999; Heckhausen ve ark., 2010). Bu çerçevede ele alındığında, seçici ikincil kontrol stratejisinin de kuramsal çerçeveye uygun bir gösterge ile temsil edildiği söylenebilir.

Daha önce de ifade edildiği gibi, birincil kontrol insan davranışı için temel itici güç olarak kabul edilmekte ve fonksiyonel açıdan önceliği bulunmaktadır. Ancak yaşın ilerlemesiyle birlikte ikincil kontrole duyulan ihtiyaç artmaktadır (Heckhausen ve Schulz, 1993; 1995; Schulz ve Heckhausen, 1996). Katılımcıların yaş aralıkları ve geçmişe dönük değerlendirme yaptıkları göz önünde bulundurulduğunda, birincil kontrolün ikincil kontrole oranla katılımcılar tarafindan daha fazla tercih edilmesinin kuramın temel varsayımlarıyla tutarlı olduğu gözükmektedir. Alan yazındaki çalışmalar da hedeften vazgeçme kapsamında değerlendirebileceğimiz stratejilerin kullanımının yaşa bağlı olarak arttığına işaret etmektedir (Brandtstädter ve Renner, 1990; Wrosch, Heckhausen ve Lachman, 2000). Ayrıca hedeften vazgeçmenin hedefi elde etme firsatlarının görece daha düşük olduğu ileri yaştaki bireyler için daha uyum sağlayıcı bir strateji olduğu da öne sürülmüştür (Haase ve ark., 2013). Ülkemizde yürütülen bir çalışma kapsamında da genç yetişkinlik döneminde birincil kontrol stratejisinin, ikincil kontrol stratejisinden daha fazla kullanildığı görülmüştür. Çalışma kapsamında ayrıca birincil kontrolün kullanımının yaşla birlikte anlamlı bir azalma göstermediği ve yaşın ilerlemesiyle ikincil kontrol stratejilerinin de en az birincil kontrol stratejileri kadar sıklıkla kullanıldığı ortaya konulmuştur (Uçanok, 2002b). Bu kapsamda birincil kontrol açısından mevcut çalışmadan elde edilen sonuçların araştırmalardan elde edilen sonuçlar ile uyumlu olduğu söylenebilir.

Niteliksel veri analizi sonucunda katılımcılar tarafından en az başvurulan stratejinin ödünleyici ikincil kontrol stratejisi (\%4) olduğu görülmüştür. Mevcut araştırma kapsamında yapılan nicel analizler sonucunda da Yaşam Boyu Gelişimde Motivasyon Kuramı (Heckhausen ve ark., 2010) çerçevesinde öne sürülen kontrol stratejilerinden ödünleyici ikincil kontrolün diğer stratejilere oranla daha az kullanıldığı ortaya konulmuştur. Analizler ayrıca seçici birincil kontrol stratejisinin seçici ikincil kontrol ve ödünleyici birincil kontrolden daha çok kullanıldığına işaret etmektedir. Belirtildiği gibi ödünleyici ikincil kontrol elde edilmesi güç olan hedefin değerini azaltmayı, olası diğer hedeflerin ise değerini arttırmayı içerir ve benliği korumaya yönelik stratejileri kapsar (Heckhau- 
sen ve ark., 2010). Hedefi üniversiteye devam etmek veya iyi bir kariyer sahibi olmak olan genç bir bireyin kendisinden daha kötü durumda olan kişilerle kendi durumunu k1yaslaması ve hedefinden vazgeçmesi, bir başka ifadeyle, ödünleyici ikincil kontrol stratejisini kullanması işlevsel gözükmemektedir. Bu doğrultuda bireyin hedefine ulaşmak için zamana ve çabaya yatırım yapması, tekrar denemesi ve mücadele etmesi (seçici birincil kontrol); zorluk çektiği konularda diğer insanlardan yardım istemesi veya tavsiye alması gibi (ödünleyici birincil kontrol) bireyin hedefle olan zihinsel bağını sürdürmesine katkı sağlayacak stratejileri daha çok kullanması anlaşılır gözükmektedir.

Belirli bir yaşam dönemine özgü gelişimsel görevlere uygun hedefler belirlemenin uyum sağlayıcı olduğu ve bireyin öznel iyilik haline olumlu yönde katkı yaptığı vurgulanmaktadır (Salmela-Aro, 2009). Bununla birlikte hedef belirleme ancak belirlediğimiz hedefi elde etmek için çaba harcadığımız durumda uyum sağlayıcı bir süreçtir (Freund ve Baltes, 2002). Bu doğrultuda bireyin belirlediği hedefe ulaşabilmek amaciyla çaba harcaması veya mücadele etmesi gerekir. Bir çalışmada (Messersmith ve Schulenberg, 2010) hedef için çaba harcama ve hedeften vazgeçme ile iyilik hali arasındaki ilişkiler incelenmiş, genç yetişkinlik döneminde çaba harcama iyilik haliyle ilişkili bulunmuştur. Aynı zamanda araştırmacılar hedef için çaba harcama ve hedeften vazgeçmede zamanlamanın önemine dikkat çekmektedirler. Buna göre, bir hedeften "zamanından önce vazgeçmenin" "tam zamanında" veya "çok geçmeden vazgeçmeye" oranla daha fazla karamsarlık ortaya çıkarabileceği üzerinde durulmaktadır. Ayrıca elde edilen sonuçlar özellikle yetişkinliğe geçiş sürecinde bir hedefe ulaşmak için çaba harcamanın iyilik hali açısından olumlu sonuçları olabileceğine işaret etmektedir. Özetlenen araştırma bulguları ve mevcut araştırma kapsamında elde edilen sonuçlar bir arada değerlendirildiğinde, bireylerin büyük ölçüde belirledikleri hedefi elde etmek için çaba harcamaya devam etmelerinin, bir başka ifadeyle hedefle olan bağlılıklarını sürdürmelerine yardımcı stratejileri daha sıklıkla tercih etmelerinin iyilik hallerine olumlu yönde katkı yapabileceği düşünülmektedir.

Araştırma bulgularından da görülebileceği gibi ilgili modele ilişkin çalışmalar ağırlıklı olarak Batı ülkelerinde yürütülmüştür. Yaşam Boyu Gelişimde Motivasyon Kuramı’nda öne sürülen birincil kontrolün önceliğinin tüm kültürlerde değişmez olduğu yönündeki görüşün tartışmaya açık olduğu ifade edilmekle birlikte (Gould, 1999), hem mevcut çalışma hem de ülkemizde konuyla ilgili yürütülen diğer çalışmanın (Uçanok, 2002b) bulguları birincil kontrolün ikincil kontrole tercih edildiğini açıkça ortaya koy- 
muştur. Yakın zamanda Japon üniversite öğrencileriyle yürütülen bir çalışmada da birincil kontrol kapsamında ele alınan doğrudan kişisel kontrolün katılımcılar arasında daha çok tercih edildiği görülmüştür. Elde edilen bu yöndeki bulgular, kontrol stratejisinin tercihinde etkili olabilecek bireysel faktörlerin (örn., durumun ne kadar acil olduğu, toplumsal ahengi bozacağı endişesi) daha ayrıntılı bir biçimde incelenmesinin gerekliliğine işaret etmektedir (Sawaumi, Yamaguchi, Park ve Robinson, 2015).

Algılanan destek açısından sonuçlar incelendiğinde ise belirlenen hedefle bağlantılı olarak bireylerin yakın çevrelerinden yüksek oranda destek algıladıkları görülmüştür. Bireyler ayrıca lise ve üniversiteye devam ettikleri yıllarda belirledikleri hedefle bağlantılı olarak en çok annelerinden destek algıladıklarını ifade etmişlerdir. Farklı destek kaynaklarının bireyin yaşamındaki koruyucu rolüne pek çok çalışmada değinilmiştir (Helsen, Vollebergh ve Meeus, 2000; Piko, 2000; Stice, Ragan ve Randall, 2004). Bununla birlikte ergenlik döneminde özellikle ebeveynden algılanan desteğin bireyin yaşamındaki önemine dikkat çekilmektedir (Helsen ve ark., 2000). Daha önce belirtildiği üzere, araştırma kapsamında hedefe ulaşmak için başkalarından tavsiye alma ve yardım isteme olarak tanımlayabileceğimiz ödünleyici birincil kontrol stratejisinin katılımcilar tarafından sıklıkla kullanılan bir strateji olduğu ortaya konulmuştur. Sözü edilen bulgu genç bireylerin belirledikleri hedefle bağlantılı olarak yakın çevrelerinden yüksek oranda destek algıladıkları yönündeki bulguyla da büyük ölçüde örtüşmektedir.

Sonuç olarak, çoğunlukla eğitim ve meslek yaşamıyla ilgili hedeflerin belirlendiği lise ve üniversite yıllarında (Salmela-Aro ve ark., 2007; Tynkkynen ve ark., 2014) bireylerin engellerle karşılaşmaları durumunda, büyük ölçüde hedeflerini elde etmek için çaba harcamaya devam ettikleri ve hedeflerinden hemen vazgeçmedikleri görülmüştür. Bireylerin ayrıca, iyi bir bölüm ve üniversiteye yerleşmek veya iyi bir meslek sahibi olmak için daha fazla çalışma, zamana ve çabaya yatırım yapma, tekrardan deneme, yeni yöntemlere başvurma ve diğer insanlardan yardım isteme gibi stratejileri daha çok kullandıkları ortaya konulmuştur. Ancak araştırma bazı sınırlılıklara da sahiptir. Bunlardan ilki, araştırma deseninin enlemesine kesitsel olmasıdır. Bu nedenle, yapılacak boylamsal araştırmalarla lise yılları ve üniversite yaşamı boyunca hedeflerin nasıl belirlendiği, belirlenen hedeflere ne ölçüde ulaşıldığı, hedeflerin içeriğinde veya hedefe ulaşma sürecinde kullanılan stratejilerde zaman içerisinde bir değişimin olup olmadığı gelişimsel olarak değerlendirilebilir. Araştırmanın bir diğer sınırlılığg ise katılımcıların kendilerine yöneltilen açık uçlu soruya geriye dönük olarak cevap vermiş olmalarıdır. Buna karşılık açık 
uçlu soruya verilen cevaplar ile kontrol stratejilerini belirlemeye yönelik kullanılan ölçme aracından elde edilen sonuçların büyük ölçüde örtüştüğü gözlenmiştir. Bununla birlikte hem nitel hem de nicel araştırma yönteminin bir arada kullanılmış olmasının araştırmanın güçlü bir yanı olduğu düşünülmektedir. Her iki yöntemin bir arada kullanılması, bütüncül bir bakış açısıyla araştırma sorularına cevap aranmasını sağlamıştır. Çalışma kapsamında nitel yöntemin doğasına uygun olarak ayrıntılı bir değerlendirmeye gidilmiştir. Belirtilen stratejiler (örn., "Başaracağıma inanıp devam ettim”) sadece üst kategorilere (örn., seçici ikincil kontrol) değil, ilgili alt kategorilere de (örn., bir hedefe ulaşmanın olumlu sonuçlarını önceden tahmin etme, bir hedefin değerini yükseltme) kodlanmıştır. Böylelikle yalnızca hangi stratejinin daha sık kullanıldığı ortaya konulmakla kalmamış, aynı zamanda alt kategorilere ilişkin de daha detaylı bilgiler elde edilmiştir. Ayrıca, ilgili alan yazında nicel yöntemle yürütülen çalışmalardan farklı olarak kontrol stratejileri daha genel ve hipotetik durumlar üzerinden değil, doğrudan yaşamın farklı alanlarında karşılaşılan zorluklar dikkate alınarak nitel analiz ile incelenmiştir. Nicel analiz kapsamında da strateji düzeyinde nitel analizden elde edilen bulgular desteklenmiştir.

Hedefe ulaşma süresince bireyler sahip oldukları olanakları, firsatları ve aynı zamanda sınırlamaları da dikkate alarak farklı stratejileri tercih etmektedir. İleride yapılacak araştırmalarda hedefin peşinden koşma sürecinde bireysel farklılıklara yol açabilecek faktörler (örn., iyimserlik eğilimi, hedeften vazgeçme kapasitesi vb.) daha ayrıntılı olarak incelenebilir (Heckhausen ve Wrosch, 2016). Ayrıca, birbirleriyle çatışan hedefler belirlemenin hedefe ulaşmayı olumsuz yönde etkileyebileceği öne sürülmektedir (Boudreaux ve Ozer, 2013). Mevcut araştırma kapsamında tek bir hedef için bireylerden kullandıkları stratejileri yazmaları istenmiştir. Birbirleriyle çatışan hedeflere sahip olmanın kaynaklarının doğru kullanımını engelleyebileceği düşünüldüğünde, ileride yapılacak çalışmalarda hedeflerin birbirleriyle ne ölçüde uyumlu oldukları veya çatıştıkları ve kullanılan stratejilerin buna bağlı olarak farklılaşıp farklılaşmadığı incelenebilir.

Çalışmadan elde edilen sonuçların okul tercihinden, alan seçimine veya mesleki hedeflerin belirlenmesinden kariyer planlarının oluşturulmasına dek uzanan geniş bir aralıkta genç bireylere sunulacak rehberlik veya danışmanlık hizmetlerine destek sağlayabileceği düşünülmektedir. Örneğin, ülkemizde lise öğrencileriyle yürütülen bir çalışmada hedef belirleme ve hedefe olan bağlılığı sürdürmeye yardımcı bir rehberlik programının etkililiği değerlendirilmiş ve programın genç bireylerin işlevsellikleri (yaşam doyumu) açısından önemi ortaya konmuştur (Eryılmaz, 2012). Bu kapsamda, bi- 
reyler kendi ilgileri, yetenekleri ve aynı zamanda içinde bulundukları koşulların onlara sunduğu olanakları ya da sınırlamaları göz önünde bulundurarak kendileri için uygun olan hedefi belirleyebilir ve belirledikleri bu hedefe ulaşma sürecinde engellerle karşılaşmaları durumunda sözü edilen stratejileri daha etkin bir biçimde kullanabilirler. Diğer taraftan, depresyon tanısı almış bireylerle yürütülen bir çalışmada, tanı almış bireylerin almamış bireylere kıyasla çözülmesi zor problemler üzerinde daha az vakit harcadıkları ortaya konulmuştur (Koppe ve Rothermund, 2017). Bu doğrultuda klinik örneklemler üzerinde yürütülecek araştırmalarla da etkin ve işlevsel strateji kullanımının bireyin sağlıklı gelişimine olan katkısı ortaya konabilir.

Hakem Değerlendirmesi: Dış bağımsız.

Çıkar Çatışması: Yazarlar çıkar çatışması bildirmemiştir.

Finansal Destek: Yazarlar bu çalışma için finansal destek almadığını beyan etmiştir.

Peer-review: Externally peer-reviewed.

Conflict of Interest: The authors have no conflict of interest to declare.

Grant Support: The authors declared that this study has received no financial support.

\section{Kaynakça}

Baltes, P. B. ve Baltes, M. M. (1990). Psychological perspectives on successful aging: The model of selective optimization with compensation. In P. B. Baltes ve M. M. Baltes (Eds.), Successful aging: Perspectives from the behavioral sciences (pp. 1-34). New York: Cambridge University Press.

Boudreaux, M. J. ve Ozer, D. J. (2013). Goal conflict, goal striving, and psychological well-being. Motivation and Emotion, 37, 433-443.

Brandtstädter, J. ve Renner, G. (1990). Tenacious goal pursuit and flexible goal adjustment: Explication and age-related analysis of assimilative and accommodative strategies of coping. Psychology and Aging, 5(1), 58-67.

Chang, E. S., Chen, C., Greenberger, E., Dooley, D. ve Heckhausen, J. (2006). What do they want in life? The life goals of a multi-ethnic, multi-generational sample of high school seniors. Journal of Youth and Adolescence, 35(3), 302-313.

Dietrich, J., Parker, P. ve Salmela-Aro, K. (2013). Phase-adequate engagement at the post-school transition. Developmental Psychology, 48(6), 1575-1593.

Dunne, E., Wrosch, C. ve Miller, G. E. (2011). Goal disengagement, functional disability, and depressive symptoms in old age. Health Psychology, 30(6), 763-770.

Eryılmaz, A. (2012). Pozitif psikoterapi bağlamında geliştirilen ergenler için amaçları genişletme grup rehberliği programının etkililiğinin incelenmesi. Eğitim ve Bilim, 37(164), 3-19.

Freund, A. M. ve Baltes, P. B. (2002). Life-management strategies of selection, optimization and compensation: Measurement by self-report and construct validity. Journal of Personality and Social Psychology, 82(4), 642-662. 
Gould, S. J. (1999). A critique of Heckhausen and Schulz's (1995) life-span theory of control from a cross-cultural perspective. Psychological Review, 106, 597-604.

Haase, C. M., Heckhausen, J. ve Wrosch, C. (2013). Developmental regulation across the life span: Toward a new synthesis. Developmental Psychology. 49(5), 964-972. doi: 10.1037/a0029231.

Hamm, J. M., Perry, R. P., Chipperfield, J. G., Heckhausen, J. ve Parker, P. C. (2016). A motivationenhancing treatment to sustain goal engagement during life course transitions. Motivation and Emotion, 40(6), 814-829.

Hamm, J. M., Stewart, T. L., Perry, R. P., Clifton, R. A., Chipperfield, J. G. ve Heckhausen, J. (2013). Sustaining primary control striving for achievement goals during challenging developmental transitions: The role of secondary control strategies. Basic and Applied Social Psychology, 35(3), 286-297.

Haverstock, N. B., Ruthig, J. C. ve G. Chipperfield, J. (2019). Primary and secondary control strategies and psychological well-being among familial caregivers of older adults with dementia. The Journal of Social Psychology, doi: 10.1080/00224545.2019.1592095.

Heckhausen, J. (1999). Developmental regulation in adulthood: Age-normative and sociostructural constraints as adaptive challenges. New York, NJ: Cambridge University Press.

Heckhausen, J., Chang, E. S., Greenberger, E. ve Chen, C. (2013). Striving for educational and career goals during the transition after high school: What is beneficial? Journal of Youth and Adolescence, 42, 1385-1398.

Heckhausen, J. ve Schulz, R. (1993). Optimization by selection and compensation: Balancing primary and secondary control in life span development. International Journal of Behavioral Development, 16(2), 287-303.

Heckhausen, J. ve Schulz, R. (1995). A life-span theory of control. Psychological Review, 102(2), 284304.

Heckhausen, J., Schulz, R. ve Wrosch, C. (1998). Developmental regulation in adulthood: Optimization in primary and secondary control. Technical Report, Max Planck Institute for Human Development, Berlin, Germany.

Heckhausen, J. ve Wrosch, C. (2016). Challenges to developmental regulation across the life course: What are they and which individual differences matter? International Journal of Behavioral Development, 40(2), 145-150.

Heckhausen, J., Wrosch, C. ve Schulz, R. (2010). A motivational theory of life-span development. Psychological Review, 117(1), 32-60.

Heckhausen, J., Wrosch, C. ve Schulz, R. (2019). Agency and motivation in adulthood and old age. Annual Review of Psychology, 70, 191-217.

Helsen, M., Vollebergh, W. ve Meeus, W. (2000). Social support from parents and friends and emotional problems in adolescence. Journal of Youth and Adolescence, 29(3), 319-335.

Jobin, J. ve Wrosch, C. (2016). Goal disengagement capacities and severity of disease across older adulthood: The sample case of the common cold. International Journal of Behavioral Development, 40, 137-144.

Koppe, K. ve Rothermund, K. (2017). Let it go: Depression facilitates disengagement from unattainable goals. Journal of behavior therapy and experimental psychiatry, 54, 278-284.

Kurt, D. ve Uçanok, Z. (2019). Gelişimsel hedefler ve iyilik halinin beliren yetişkinlerde incelenmesi. Psikiyatride Güncel Yaklaşımlar, 11(Araştırma özel sayısı 1), 118-135.

Kuş, E. (2006). Bilgisayar destekli nitel veri analizi. (Yayınlanmamış Doktora Tezi), Ankara Üniversitesi, Sosyal Bilimler Enstitüsü, Ankara. 
Messersmith, E. E. ve Schulenberg, J. E. (2010). Goal attainment, goal striving, and well-being during the transition to adulthood: A ten-year U.S. national longitudinal study. New Directions for Child and Adolescent Development, 130, 27-40.

Nurmi, J. E. (2004). Socialization and self-development: Channeling, selection, adjustment, and reflection. In R. M. Lerner ve L. Steinberg (Eds.), Handbook of adolescent psychology (pp. 85124). Hoboken, NJ: Wiley.

Piko, B. (2000). Perceived social support from parents and peers: Which is the stronger predictor of adolescent substance use? Substance Use \& Misuse, 35(4), 617-630.

Rothbaum, F., Weisz, J. R. ve Snyder, S. S. (1982). Changing the world and changing the self: A twoprocess model of perceived control. Journal of Personality and Social Psychology, 42(1), 5-37.

Russell, A. ve Anderson, S. F. (2018). The relationship between self-regulatory strategies, daily stress, and negative affect in college females: An analysis of typical levels and intraindividual variability. Emerging Adulthood, doi: 10.1177/2167696818775149.

Salmela-Aro, K. (2009). Personal goals and well-being during critical life transitions: The four C'sChanneling, choice, co-agency and compensation. Advances in Life Course Research, 14, 63-73.

Salmela-Aro, K., Aunola, K. ve Nurmi, J.-E. (2007). Personal goals during emerging adulthood: A 10year follow-up. Journal of Adolescent Research, 22(6), 690-715.

Sawaumi, T., Yamaguchi, S., Park, J. ve Robinson, A. R. (2015). Japanese control strategies regulated by urgency and interpersonal harmony: Evidence based on extended conceptual framework. Journal of Cross-Cultural Psychology, 46(2), 252-268.

Schilling, O. K., Wahl, H. W., Boerner, K., Horowitz, A., Reinhardt, J. P., Cimarolli, V. R., ... Heckhausen, J. (2016). Developmental regulation with progressive vision loss: Use of control strategies and affective well-being. Developmental Psychology, 52(4), 679-694.

Schneider, B. ve Stevenson, D. (1999). The ambitious generation. Educational Leadership, 57(4), 22-25.

Schulz, R. ve Heckhausen, J. (1996). A life span model of successful aging. American Psychologist, 51(7), 702-714.

Shane, J. ve Heckhausen, J. (2016). For better or worse: Young adults' opportunity beliefs and motivational self-regulation during career entry. International Journal of Behavioral Development, 40(2), 107-116.

Stice, E., Ragan, J. ve Randall, P. (2004). Prospective relations between social support and depression: Differential direction of effects for parent and peer support? Journal of Abnormal Psychology, $113(1), 155-159$.

Şahin, İ., Zoraloğlu, Y. R. ve Fırat, N. Ş. (2011). Üniversite öğrencilerinin yaşam amaçları, eğitsel hedefleri üniversite öğreniminden beklentileri ve memnuniyet durumları. Kuram ve Uygulamada Ĕ̈itim Yönetimi, 3(3), 429-452.

Tynkkynen, L., Dietrich, J. ve Salmela-Aro, K. (2014). Career goal-related success expectations across two educational transitions: A seven-year longitudinal study. European Journal of Developmental Psychology, 11(3), 356-372.

Uçanok, Z. (2001). Gelişimsel düzenleme modeli çerçevesinde genç yetişkin, orta yaş ve yaşlılıkta kontrol stratejilerinin incelenmesi. (Yayınlanmamış Doktora Tezi), Hacettepe Üniversitesi, Sosyal Bilimler Enstitüsü, Ankara.

Uçanok, Z. (2002a). Gelişimsel düzenleme modelinin psikometrik olarak incelenmesi. Psikiyatri, Psikoloji, Psikofarmakoloji Dergisi (3P), 10(2),141-153.

Uçanok, Z. (2002b). Gelişimsel düzenleme modeli: Yetişkinlikte kontrol stratejilerinin incelenmesi. Türk Psikoloji Dergisi, 17(49), 1-16. 
Uno, M., Mortimer, J. T., Kim, M. ve Vuolo, M. (2010). "Holding on" or "coming to terms" with educational underachievement: A longitudinal study of ambition and attainment. New Directions for Child and Adolescent Development, 130, 41-56.

Varjas, K., Nastasi, B. K., Moore, R. B. ve Jayasena, A. (2005). Using ethnographic methods for development of culture specific interventions. Journal of School Psychology, 43, 241-258. doi:10.1016/j.jsp.2005.04.006

Vasalampi, K., Salmela-Aro, K. ve Nurmi, J. E. (2009). Adolescents' self-concordance, school engagement, and burnout predict their educational trajectories. European Psychologist, 14(4), 332341.

Versey, H. S. (2015). Managing work and family: Do control strategies help? Developmental psychology, 51(11), 1672-1681.

Wrosch, C., Heckhausen, J. ve Lachman, M. E. (2000). Primary and secondary control strategies for managing health and financial stress across adulthood. Psychology and Aging, 15(3), 387-399.

Wrosch, C., Schulz, R. ve Heckhausen, J. (2002). Health stresses and depressive symptomatology in the elderly: The importance of health engagement control strategies. Health Psychology, 21(4), 340-348.

Yavuzer, H., Demir, İ., Meşeci, F., ve Sertelin, Ç. (2005). Günümüz gençliğinin gelecek beklentileri. Hasan Ali Yücel Ĕgitim Fakültesi Dergisi, 2, 93-103.

Yüksek Öğretim Kurumu (YÖK) (2019, 27 Ekim). Ylllara göre üniversitelere başvuran ve yerleşen aday sayıları. Erişim adresi: https://istatistik.yok.gov.tr/images/ykgi/YILLARA_GORE_ UNIVERSITELERE_BASVURAN_YERLESEN_ADAY_SAYILARI.pdf 
